\title{
FEHÉR BENCE
}

\section{Rovásírással - latinul}

The Hungarian Runic script (or, according to another terminology, Szekler script), rarely used in the 10th-14th centuries, had got some popularity in the era of the Renaissance. There are a few examples, where the letters, originally devised for the Hungarian language, were combined with or used for Latin words. Thus the author of the Sepsikilyén wall graffito wrote X Jcribfit $\circ \leftarrow \mathrm{BNDK}^{2} \mathrm{I}[[\mathrm{L}]]^{\prime} \mathrm{Ly}^{\prime} \mathrm{ES}$, that is, Benedek Illyés scripsit; probably there is another hic fuit-graffito in Berekeresztúr from 1581, written partly in Runic script. The most prominent example is István Szamosközy's Latin epigram from 1604, a pasquin against Emperor and King Rudolph, where Runic script was used as kind of a cryptography, the author had to set several orthographic rules for the Latin language in Runes and partially accommodated the graphotactics to the Latin custom too. ${ }^{1}$

Az ún. (magyar/székely) rovásírás ${ }^{2}$ vagy székely írás ${ }^{3}$ (természetesen mindkét elnevezés modern terminus technicus, a későreneszánsz idején

${ }^{1}$ A publikáció az MTA-SZTE Antikvitás és Reneszánsz: Források és Recepció Kutatócsoport (TK2016-126) támogatásával jelent meg.

2 Ez a terminus SEBESTYÉN Gyulára (1909) megy vissza, aki az emlékek első rendszerező és elemző közlésekor az írást eredetileg fába rótt jelekként értelmezte. A későbbiekben ő azonban magyar rovásírásnak nevezte (SEBESTYÉN 1915), a székely rovásírás kifejezés, amely a régi "hun-székely" elnevezéssel való kontaminálódást, ill. a felismerést mutatja, hogy emlékei nem összmagyar elterjedésűek, először 1929-ben bukkan fel nála (SEBESTYÉN 1929). A nem-összmagyar jellegben azonban a legújabb felfedezések, elsőrendüen az alsóbüi felirat tükrében már ismét jogos kételkednünk.

3 SÁNDOR (2014a), már könyve címében (korábbi publikációiban ő is használja a rovásírás kifejezést), de elvi éllel is kifejtve, mivel specifikusan a székelység írásának tartja; őt követve a kutatók egy csoportja mára átvette: így elsősorban TUBAY Tiziano (2015). Szórványosan már korábban is használták, az első kutató, aki szisztematikusan élt vele, azonban elvileg nem indokolta a terminust, alighanem VÉKONY Gábor volt (1999) és (2004). El kell ismerni, hogy az első, reneszánsz kori írásos említés, az ún. Nikols- 
az első kodifikáló, Telegdi János hun (vulgo székely) betüknek nevezte, ${ }^{4}$ és a 19. század közepéig kisebb-nagyobb variációkkal ez az elnevezés volt közkeletü) ${ }^{5}$ fennmaradt emlékeinek igen tekintélyes része a reneszánsz korra megy vissza, olyannyira, hogy szkeptikus kutatók régóta megfogalmaztak olyan elméletet, hogy voltaképpen humanista bölcsészek alkották meg a múlt megidézése, titkosírás vagy hasonló célból. ${ }^{6}$ Ennek az elméletnek a totális cáfolatát nem egyéb adja, mint a 10-15. század közti időből ma ismert néhány rovásírásos felirat. ${ }^{7}$ Nyilvánvaló azonban,

burgi ABC közelítőleg ezt a kifejezést használja: Litter(a)e Siculorum quas sculpî(n)t I vel cidunt in lignis 'a székelyek betűi, melyeket fába rónak avagy metszenek', de semmi okunk úgy gondolni, hogy az $\mathrm{ABC}$ nem is magyar leírója egy abban a korban valóban bevett terminust fordított volna le, nem pedig ad hoc fogalmazott.

4 Johannes Telegdi, Rudimenta priscae Hunnorum linguae, brevibus quaestionibus ac responsibus comprehensa, Lugduni Batavorum (?) 1598: De litteris Hunnorum, quae vulgo litterae Siculorum vocantur.

${ }^{5}$ Elsősorban Bél Mátyás hatására (aki Kaposi Sámuel elveszett kéziratát közvetítette): Matthiae Belii De Vetere Literatura Hunno-Scythica Exercitatio, Lipsiae 1718.; mások megelégedtek a hun betûk kifejezéssel (így a legismertebb: Francisci Otrokocsi Fóris, Origines Hungaricae, Franequerae 1693, 320-321), de néhány kivétel is van, akik a 17-19. században másképp nevezték meg: egy 17. századi anonymusnál Régÿ magiar beoteok (idézi JERNEY 1840, 113.); a 18. században már inkább hun-scytha betűk (így Jos. Innocentius Desericzky, De iniiis ac majoribus Hungarorum liber III, Budae 1753, 144-156, Stephanus Hájos, Monumentum Literarium Hunno-Scythicum, Annopoli s.a., ms. MTAK M.Nyelvt. 2r 3., és utána számosan nyomtatásban is, nyilván elsősorban Ioannis Nicolai Révai, Elaboratior Grammatica Hungarica, Pestini 1806, I 146. közvetítésével).

${ }^{6}$ RÉTHY (1888). Még a 21. század elején is felvetődött komoly formában: HORVÁTH (2010). Ekkor már azonban komolytalansága annyira nyilvánvaló volt, hogy a felelevenítő Horváth Iván maga is kénytelen volt részben visszavonni tézisét: HORVÁTH et al. (2011).

7 A legkorábbi, amelyet a szakmai konszenzus elfogad, a bodrog-alsóbűi felirat a 10 . század első feléből (VÉKONY [1999: 7. kép], BENKŐ [2012: 48; 60] - szerinte székely eredetü -, SÁNDOR [2014a: 103-115], TUBAY [2015: 148-149] stb., datálására: GÖMÖRI [2000: 170]); mára nagyjából egyetértés van abban is, hogy a homoródkarácsonyfalvi és vargyasi feliratok a 13-14. századnál nem újabbak (BENKŐ [1994a: 161-164], BENKŐ [1994b], KÓNYA [1994], VÉKONY [2004: 9-16, 111-117], BENKŐ [2014: 317-318], SÁNDOR [2014a: 177-182] stb.). Saját kutatásaim (autopsziás vizsgálat) alapján állíthatom, hogy a firtosvári töredékes felirat hiteles, keletkezése a 12. század végére-13. századra valószínűsíthető (FEHÉR [2019]). Teljesség igénye nélkül, véleményem szerint a középkorba sorolhatók még a többi firtosvári töredékek, az erdőszentgyörgyi, a berekeresztúri torony II. emeletének felirata. BENKŐ Elek talán jogosan teszi a 15. század elejére a szé- 
hogy a 15. század végétől a rovásírás emlékei hirtelen gyakoribbak, különböző humanistáknál előforduló említéseik szaporodnak, minta-ABCt írnak le (a Nikolsburgi $\mathrm{ABC}^{8}$ ), míg végül 1598-ban Telegdi János elkészíti a kodifikált leírást - egyszóval a reneszánsz korban divatba jön, és Telegdi után már elsősorban irodalmi, tudós hagyományon alapuló emlékei keletkeznek, nem a népi írástudás gyérülő maradványai.

Tulajdonképpen nincs tehát abban semmi meglepő, ha a tudós elmék, akik e korban még rendszerint szívesebben, de legalábbis könnyedebben fogalmaznak latinul, alkalomszerúen nemcsak a magyar nyelvet, hanem latin szöveget is megörökítenek a "hun" betükkel. Természetesen a tipikus az, hogy ha egy emléken latin és magyar szöveg is van, a latin szöveg mindenképp latin betűkkel születik, a magyar szöveg esetleg lehet rovással. ${ }^{9}$ Ennek szép, eddig azonosítatlan és nem is irodalmi, hanem köznépi, graffitón jelentkező példája a sepsikilyéni felirat, ahol a falfestmény keretén összesen öt, fraktúr és kapitális betüs 15-16. századi latin (és egy olvashatatlan, tehát kétes nyelvű) hic fuit-felirattöredék mel-

kelydályai A feliratot (BENKŐ [1996: 75-77]), bár megállapítása, hogy a még nedves vakolatba karcolták, kétes (bizonyosan téved abban, amikor a B és C feliratot ezzel egykorúnak tartja), ezzel szemben kései a bögözit a 15. század végére tenni (BENKŐ [1994a: 164-65 n. 4]), mivel az minden logika szerint egykorú a freskóval, tehát éppen BENKŐ értékelése alapján szintén 14/15. század fordulója.

${ }^{8}$ JAKUBOVICH (1935), ill. azóta szinte megszámlálhatatlan újraközlésben.

${ }^{9}$ A tudtunkkal legrégebbi példa vsz. a Suki-kehely, amelynek talpán Pál Endre azonosított egyszavas, rovásírásos bekarcolást (PÁL 1966: 109). Sajnos ez a mai napig megfejtetlen, ERDÉLYI István (1999: (en)ghem<e>t) olvasata írástechnikai szempontból magyarázhatatlan, értelme pedig nincs. A kehely négy "hivatalos" felirata természetesen latin nyelvü, latin fraktúr betűs díszírás. A dálnoki felirat folytatása (1526-ból) fraktúr latin betűs díszírás (első közlése: BENKŐ [1981]); teljesen ugyanez a helyzet Énlakán, ahol a felirat latin része latin betüs, magyar része rovásos, míg emellett még tíz (!) helyen áll tisztán latin szöveg - közlésük általában már ORBÁN (1868: I 124), de az elpusztult kórusfelirat lejegyzése csak kéziratban maradt ránk, ms. MUEKV Gylvt. 1801.I.20. Lázár István püspök visitatiós jegyzőkönyve 151-152, ed. FEHÉR (2017: 310; 314 [9. kép]). Az olvasat bizonytalansága miatt nem térek ki a pécsi mesterjegyes címerre (FORRAI [1987: 48-51]), amelyen mintha ugyanaz a két jel ismétlődnék latin és rovásbetűkkel. Olyan is előfordul, nem is egyszer, hogy egy templomvakolat latin hic fuitgraffitiözönében bukkan fel egy rovásírásos név magyarul (Berekeresztúr, Rugonfalva), de ezeknél persze nem ugyanarról a feliratról van szó két nyelven. 
lett áll az 1978-ban felfedezett ${ }^{10}$ rovásfelirat, amelyet azonban eddig még nem olvastak ki pontosan. ${ }^{11}$ A helyes olvasat a következő: X fcribfit (!) 。 $\leftarrow \mathrm{BNDK}^{2} \mathrm{I}[[\mathrm{L}]]$ 'Ly'ES. Az amúgy ismeretlen 15. század végi-16. század elei graffitiző és múkincsrongáló, Benedek Illyés tehát először egy keresztet jelölt (vagy esetleg neve kezdőbetüjét rovásjellel?), majd fraktúr latin betűkkel, tanulatlan latinsággal közölte, hogy írt, és végül a saját nevét magyarul, rovásírással (abban sem volt elsőre sikeres, keresztnevében a L jelet javítani volt kénytelen Ly-re). De nem kivétel nélkül így történt!

Egy rövid spontán latin szöveg jelenik meg a Marsigli-féle rovásemlék naptárrészének végén: E?TSIK ${ }^{2}$ FINIS, tehát: et sic finis, és így van vége. ${ }^{12}$ Nyilván, mivel ez egy átirat az eredeti botról (sőt olyan feltevés is van, hogy csak az eredeti botról készült átiratról), nem lehet bizonyítani, hogy ez az eredeti naptárbotnak is a részét képezte, ${ }^{13}$ és nem csak a másoló megjegyzése. Mindenesetre a lejegyző feltétlenül magyar volt: a latin $S$ betüt a rovásírás $\Lambda$ karakterével jelölte, vagyis magyar S-nek ejtette.

Ha némileg bizonytalan észleletem helyes, a népi írástudásnak egy graffito-emlékén legalább egy rovásbetü latin szövegre vonatkozik a berekeresztúri templomban. E templom 15-16. századi vakolatában több rovásírásos felirat maradt ránk, amelyeket számos munka tárgyal; ezek száma azonban valójában eltörpül a templomtornyot szinte elborító latin hic fuit-graffititől, amelyek teljességükben nincsenek közölve, még

${ }^{10}$ KÓNYA (1982). A freskókat 1887-ben Huszka J. tárja fel először, újra bemeszeltetik, 1977-ben földrengés során kerülnek elő újra; Kónya azonban 1982-ben még nem tesz említést a rovásfeliratról.

11 RÁduly (1995: 10, 34-49): $B^{e} n^{\wedge}$ diko v. Bán^diko.

${ }^{12}$ L. F. Marsigli ms. vol. 54 (Manoscritti diversi IV), 677,2,11.

${ }^{13}$ Megjegyzendő, hogy e betűk nem Marsigli, hanem a főleg a szöveg magyar átiratában alkotó $B$ írnok keze munkája, ez felveti a lehetőségét, hogy az egész kézirat végére utólag került; ez azonban nem valószínü, mivel egyes részek eleve a B írnok kezétől származnak és ott önmagát korrigálta, sőt olyan hely is van, ahol Marsigli a B ismeretében írt még bele utólag a szövegbe (vö. SÁNDOR [1991: 28-31]). Viszont azt is el kell ismerni, hogy vannak helyek, ahol a B írnok bizonyosan nem betühíven, hanem értelmezve bővítve közölte a szöveget $(675,1,2)$. 
említve is alig. ${ }^{14}$ A torony belsejében, az első emelet nyugati falán levő ablaknyílás jobb felén három nem teljesen elkülönülő oszlopban a következő graffiti olvasható (középen és jobb szélén egy-egy kisebb darabon leomlott a felület, egyébként ép, de vonalakkal, rajzokkal összekaristolva):

$a^{1} h($ ic $): f($ uit $) \quad h^{\wedge}$ (ic) $f($ uit $): P: V^{2}$ (2 pentagramma) ${ }^{3} h(\text { ic })^{\wedge} f($ uit $)$ $\mathrm{AV} \circ \mathrm{OII}{ }^{4}+(k o ̈ r){ }^{5} h($ ic $) f($ uit $) \circ I I^{6} h($ ic $) f($ uit $) h^{\wedge}$ (ic) $f($ uit $) \leftarrow h$ (ic) $f($ uit $){ }^{7}$ $\rightarrow[---]$ Mạtias $\{s s\}^{8}[---] a^{9} \lambda$ ? NIT ${ }^{10} h(i) c$ fuit Jọhanes VAST ${ }^{11} \mathrm{H} \boldsymbol{b}^{1}$ X S (vac.) $\mathrm{LJJ}^{2}$ hic fuit Matias Siklodi a n (no) $1584^{3} h^{\wedge}$ (ic) fuit (pentagramma) Matias : Vasarh^eli ${ }^{4}$ hic of $r$ uit Andreas Pasto $<r>{ }^{5}$ hic fu<it - - > $6\left[\right.$ [hic f]]<uit - - > 7 hic fuit Andreas ${ }^{8}$ Vagasi ${ }^{9}++[---]+s(?) i{ }^{10}$ $A n^{\wedge} d[r e ?] a s+{ }^{11}$ A 'A'? III ${ }^{12}$ hic fuit [- $] n[---]{ }^{13}$ (pentagramma) $c^{1}$

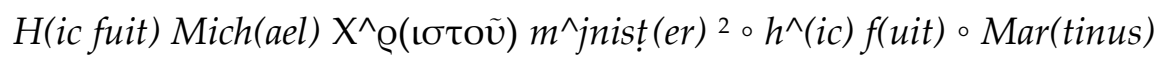
: Vas(arheli) : ${ }^{3}$ hic fuit Andreas ${ }^{4}$ Bartos h(ic) $\leftarrow$ fru $(i) t \rightarrow$ S. O. ${ }^{5} \mathrm{~h}(\mathrm{ic})$

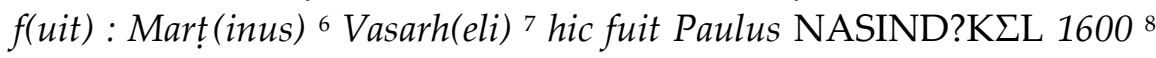
Pas(tor?) (vac.) +PIO+ [- - - ${ }^{9}$ H[ic fluit Matias Siculoidi [- - - ${ }^{10} \mathrm{HH}$ (rajz) ${ }^{11}$ (rajz) v. $h\left(\right.$ ic) f(uit) $P T(\text { ? })^{12} h^{\wedge}$ (ic) f(uit) $S($ ?)

Mint láthatjuk, önmagukban ezek a feliratok nem túlzottan érdekesek, bár tanulságosak a hasonló teleírt törökkori templomfalak kronológiája szempontjából: úgy tünik, nem követnek szoros időrendet, hanem későbbieket az üres helyeket kitöltve és a régiekre is ráírva készítettek; a szélesen, mélyen vésett és keretelt feliratokat a $c^{7} 1600$ körülre keltezi, a magasan, vékonyan, de jól olvashatóan írtak a $\boldsymbol{b}^{2}$ alapján az 1580-as évekből. Az ennél korábbi rétegre azonban jóval nagyobb kurzív betűkkel (23-32 cm) 1581-ben rákarcoltak egyetlen rövid firkát: $\leftarrow$ \ CFV $\rightarrow$ 1581.

A szöveg (?) teljesen értelmetlennek tűnik, a szám annál világosabb, és ez valószínűvé teszi, hogy a betűknek is csak volt valami jelentésük. Ha a többi felirat hic fuit-jellegéből indulunk ki, egy hasonló értelmezés elképzelhető, ha a jobbról-balra szakasz első jelét rovásírásos $\mathrm{H}$ jelnek tekintjük: $\mathrm{H}(i) \mathcal{c} f u(i t$ ?). Mindenképpen egyedülálló, szokatlan és nehezen magyarázható egy rovás- és latin jelekkel vegyes bejegyzés, még külö-

14 ERDÉLYI (2001), ERDÉLYI-RÁDULY (2010: 78), esetleg (bár az azonosítás kétes) FERENCZI (1997: 21, n.3) - ők azonban ezek egy részét megpróbálják rovásírással olvasni. 
nösebb, hogy a név hiányzik (azonban, mint említettük, a vakolat egy része mindenképp leomlott, és vannak különálló, nagy betûs karcok is, amelyeknek nem mindig lehet értelmet találni, köztük az 1581 előtti rétegben egy rovásírásos L-re hasonló, ez azonban aligha tartozhat a fenti nagy betüs jelsorhoz).

Mármost a fenti, mondhatni, szórványemlékek mellett van egy többé-kevésbé ismert (legalábbis 1880-ban kiadott, ${ }^{15}$ és 1915 óta mint rovásemlék azonosított ${ }^{16}$ ) költői szövegünk is latin nyelven: Szamosközy István második ${ }^{17}$ rovásfeljegyzése. Ez egy 1604-re keltezhető latin epigramma, a Szamosközyre jellemző tiszta nyelvhasználattal és szarkasztikus stílussal megfogalmazva. ${ }^{18}$ Noha tehát közölt szöveg, ${ }^{19}$ nem haszontalan itt a vers teljes szövegét közölni, a rovásírásos részben alkalmazva a pontos epigráfiai jelölést.

\footnotetext{
${ }^{15}$ Szamosközy István, Történeti maradványai. Ed. SZILÁGYI Sándor, Monumenta Hungariae Historica 30. Budapest 1880.
}

16 SEBESTYÉN (1915: 87-89).

17 Szamosközy első feljegyzése, amely valamikor 1587-1593 közt íródhatott (ed. SZILÁGYI 1880: 18; ms. EgyetK. Hevenesi Coll. LXVIII. 282., ma LEO 1358. 55v, 17-22.) magyar nyelvü bizalmas feljegyzés, amely helyenként latin betüs latin, helyenként rovásírásos magyar szövegbe csap át, egyértelműen titkosítás kedvéért, és még így is a szöveg egy részét utólag, az eredetinél jóval sötétebb tintával kihúzták. A rovásszövegnek tehát itt a latinhoz semmi köze nincs, és ráadásul a problémás inkább a latin betüs rész, amelyet a törlés helyenként annyira megrongált, hogy a mai napig nincs megnyugtató olvasata (jómagam sem tudtam az egészet kibetűzni, a Kendi Jftván (?)

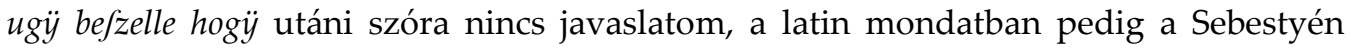
Gyula 1915-ös átirata óta elfogadott reddere igenévi alakban erősen kételkedem).

${ }^{18}$ Ed. SZILÁGYI (1880: 216); ms. EgyetK. Hevenesi Coll. LXVIII. 162, ma LEO 272. 41v (lapszámozás: 162 > 314 > 79). Rovásírásként azonosítva SEBESTYÉN (1915: 88-90) (nyilvánvaló egyébként, hogy már Szilágyi tudta, hogy miről van szó, hiszen sikerült neki nagyjából kiolvasnia és ritkított betükkel szedve közölte, csak éppen nem említette a közönségnek, mit talált).

19 Viszonylag terjedelmes a rá vonatkozó szakirodalom is: NÉMETH (1934: n. 10), CSALLÁNY (1960: 79-80, rajz: 22. kép), FORRAI (1985: 169-172), FORRAI (1994: 308-312, rajz: 116. kép), SÁNDOR (2014a: 233-237, fotó: 39. kép). Említések: JAKUBOVICH (1935: 448); FERENCZI (1936: 69, 75. jz.); FERENCZI (1939: 185); CSALLÁNY (1970: 611); VÉKONY (1985: 80); VÉKONY (1987: 19); FERENCZI (1997: 6); KOMLÓSSY (2006: 531); MANDICS (2010: III 124-125); HORVÁTH et al. (2011: 74; 82-83); SÁNDOR (2014b: 336); TUBAY (2015: 74-75). 


\section{$\leftarrow \mathrm{IN} \circ \mathrm{R}^{1} \mathrm{ODOLFV}{ }^{\wedge} \mathrm{M} \circ \mathrm{CAES}^{\wedge} \mathrm{AR}^{1} \mathrm{EM} \circ$}

Imperium per te capit incrementa [[Rodolphe]] $\rightarrow \mathrm{R}^{1} \mathrm{ODOLFE}$

Hinc etiam Augusti nobile nomen habes.

Scilicet [[implesti]] auxist $\rightarrow \mathrm{B}^{\wedge} \mathrm{ELLIS} \circ \mathrm{FV}^{\wedge} \mathrm{R}^{1} \mathrm{IALIBVS}$ orbem,

Auxisti populos $\rightarrow$ PESTE $\circ \mathrm{K}^{2} \mathrm{R}^{1 \wedge} \mathrm{VO}^{\wedge} \mathrm{R}^{1} \mathrm{E} \circ \mathrm{FAME} \circ 20$

Implesti Vngaricas $\rightarrow$ DIR ${ }^{1} \mathrm{IS} \circ \mathrm{PR}^{1} \mathrm{AEDONIBVS} \circ \mathrm{O}^{\wedge} \mathrm{R}^{1} \mathrm{AS} 。$

Dacia $\rightarrow$ PES$^{\wedge}$ TIFER $^{1} \mathrm{O} \circ \mathrm{TO}[[\mathrm{N}]]^{\prime} \mathrm{T}^{\prime} \mathrm{A} \circ \mathrm{LATR}^{1} \mathrm{ONE} \circ \mathrm{SK}^{2} \mathrm{ATET} \circ$

Nescio tot populos qua^e rerum copia ditet,

Hoc scio Praga tua quod bene crescit ope.

Quod foris hauritur $\rightarrow$ FOETV $^{\wedge} \mathrm{R}^{1} \mathrm{~A} \circ \mathrm{DO}[[\mathrm{V}]] \mathrm{ESTIK}^{2} \mathrm{~A} \circ$ supplet,

[in margine] 'DOMESTIK ${ }^{2} \mathrm{~A}$ '

Pensas $\rightarrow$ DEGLVPTO bellica damna $\rightarrow$ PENE $\circ 21$

Nam to $\rightarrow$ TINDA $^{\wedge} \mathrm{R}^{1} \mathrm{IDAS}$, to $\rightarrow \mathrm{PA}^{\wedge} \mathrm{R}^{1 \wedge} \mathrm{VOS}^{\circ} \mathrm{CAES}^{\wedge} \mathrm{AR}^{1} \mathrm{IONES}$,

Et tot $\rightarrow$ GLANDIUO $^{\wedge} \mathrm{R}^{1} \mathrm{AS}$ continet aula $\rightarrow$ LVPAS。

Quot neq(ue) multifidus uariatur cornibus Ister,

Nec tot diues aquis cornua Nilus habet.

Perge $\rightarrow \mathrm{R}^{1} \mathrm{ODOLFE} \circ \mathrm{NOTHIS}$ latè $\rightarrow$ SOBOLES[[I]] 'C'ER ${ }^{1} \mathrm{E}$ natis,

Ne desit laudi materia ampla tua^e.

Sebestyén Gyula a szöveget Rédey Tivadar müfordításával közölte, azóta mindenki ezt közli, ha a szöveg magyar értelmét akarja visszaadni. Sebestyén még nyilvánvalóan tudta, hogy ez a szöveg enyhén finomított: a mai olvasók aligha, elhiszik, hogy Szamosközy azt írta le epés dühében, amit Rédey eléjük tár. ${ }^{22}$ Valójában az invektíva nyersen szexuális tartalma ${ }^{23}$ még most, a 21. században is elég meghökkentő, szóról szóra ezt mondja:

\footnotetext{
${ }^{20}$ A T betű tükörbe fordítva, tehát valójában helyes irányban áll.

${ }^{21}$ Itt nyilvánvaló Szamosközy hibája, hiszen a pene szó első magánhangzója nem lehet rövid.

22 Sőt úgy tűnik, pontosan Szilágyi Sándor sem értette, mert a 11. és 15. sor az ő átiratában értelmetlen: nála paves caesarienses és subagescere áll. (Vajon mire gondolhatott? Rudolf császár szerinte rettegett volna a Helenáktól és császáriaktól?)

${ }^{23}$ Ez Szamosközynél egyáltalán nem meglepő. Egy másik papírlapon levő epigrammáját Szilágyi közvetlen mellette közli (ed. SzILÁGYI [1880: 216]), és ráadásul - némileg megtévesztő módon - a szexuálisan offenzív szavakat ugyanúgy ritkított betűvel szedi, így a kéziratot kezébe nem vevő olvasó azt hiheti, ez is rovás-titkosírás. Valójában azonban a Mester [érdemes lenne kivizsgálni, vajon a rovásírás-szkeptikus Réthy Lász-
} 
Rudolf császárra. I Általad gyarapodáshoz jut a birodalom, Rudolf, | innen van az Augustus neved. ${ }^{24}$ | Tudnillik őrjöngő háborúkkal [[töltötted meg]] gyarapítottad a földet, I gyarapítottad a népeket dögvésszel, vérontással, éhséggel. | Megtöltötted a magyar partokat kegyetlen fosztogatókkal, I dögletes útonállótól hemzseg az egész Dacia. I Nem tudom, milyen bőség gazdagít annyi népet, I azt tudom, hogy Prága szépen nő a te segítségeddel. I Ami külföldön elnyelődik, azt az otthoni szaporulat kipótolja, I a hadikárokat kiegyensúlyozod kihámozott farkaddal. I Mert annyi Tyndarist [= Helené], annyi kicsi Caesariont [= császári fattyú], I és annyi makkszopó szukát tart az udvar, I ahány szarvval [= deltaággal] a sokágú Duna sem oszlik meg, | amennyi szarvat a vízben bő Nílus sem birtokol. | Rajta, Rudolf, sarjadj újra széltében fattyú szülötteiddel, I ne legyen a dicséretednek hiánya bőséges alapanyagban..$^{25}$

A szöveg érdemi tanulságai természetesen nem erotika-, hanem írás- és nyelvtörténetiek.

1. A rovásírás itt egyértelműen titkosírás, a császár nevét és az öszszes felségsértő részt tartalmazza. Erről a szerző az első sorban egy pillanatra elfeledkezett, leírta a Rodolphe szót, majd nem győzte átsatírozni.

2. Nem kell külön hangsúlyozni, hogy Szamosközy, akinek előző feljegyzése 1598 előtti, nem Telegdi Rudimentájából tanulta a rovásírást, ezért egy attól független íráshagyományt tükröz. Nem az ő keze vonása azonban az egész mü: a 9. (és egy betüt a 15.) sorban javító kéz eltérő, más írásstílust használ, főleg az A és $\mathrm{K}^{2}$ jelek alakja más - viszont nem azonosítható ismert kéziratos rovásváltozattal, így a javítás datálása és

ló/Lőwy Árpád kinyomozta-e, hogy a csak latin betűs átiratban publikált invektíva rovásírásos, és nem inspirálta-e ez a mű is szépirodalmi munkásságában] bárki számára olvasható latin gyöngybetűkkel merte leírni az alábbi szavakat:

Ex corio factum gestat Germanus olisbum, ut possit tribades permoluisse suas.

(Állatbőrből készült műpéniszt visel a német, | hogy azzal dörzsölgethesse a leszbikusait.)

${ }^{24}$ Ami ugyebár etimológiailag valóban Gyarapító.

25 A rovásírásos szavakat vastagon szedtem. 
személyhez kötése sajnos nem lehetséges. Nem tartom elképzelhetetlennek, hogy a javítás akár lényegesen később történt. ${ }^{26}$

3. Szamosközy a címet normális jobbról balra haladó sorrendben írta le. Amikor azonban a szöveg közepén tért át a rovásra, logikusan úgy döntött, hogy nem változtatja meg az írásirányt (ez azonban eltér másik rováskéziratától, ahol szöveg közben is irányt váltott!), hanem balról jobbra haladt, és eközben a betüket is tükrözte - kivéve egy T-t, amelynél erről elfeledkezett. Ez aztán a későbbi javítónak sem tűnt fel, így maradt mai napig. Ez tehát egy helyzethez alkalmazható, élő írásmódnak tünik, amelyet a scriptor igények szerint közelíthet a latin írás gyakorlatához:27 ennek másik jele, hogy a címben a szókezdő betűk nagyobbak, így egyfajta kapitálist hozva létre a rovásírásban is.

4. És végül számunkra a legfontosabb, hogy a szerző egyfajta általános átírási elvet is létrehozott (vagy csak követett?) a latin szavak rögzítésére. Eszerint a latin $s$ átírása magyarosan $S$, a $c$-é palatalizált helyzetben magyar $\mathrm{C}$, egyébként $\mathrm{K}^{2}\left(\mathrm{a} \mathrm{K}^{1}\right.$ [vagy ${ }^{\mathrm{a}} \mathrm{K}$ ] jelet nem alkalmazza ${ }^{28}$ ), ennyiben tehát magyaros-fonetikus; másfelől viszont megmarad a latin minta mellett annyiban, hogy az ae és oe megfelelője $\mathrm{AE}, \mathrm{OE}$ digráf. A legjellemzőbb azonban az $u / v$ betűpár kezelése, amely (bár nem teljesen kivétel nélkül) a maihoz képes fordított: az $u$ jele $\mathrm{V}$, a v-é $\mathrm{U}$. Ez azonban ténylegesen csak egy $U$ jelet jelent, amire lehet a magyarázat akár nagyon egyszerü is: az AE és OE digráfokhoz hasonlóan a latin írás vizuális képét követte, amennyiben a nagybetüs feliratos írásformának elképzelt szövegben jelölte $\mathrm{V}$-vel az $u$-t; első alkalommal, a 11. sorban a parvos szóban is megmaradt ennél, viszont a következő szóban, az intervokális v-nél feltünt neki a probléma, hogy egy a rovásírásban teljesen különböző jellel bíró fonéma előtt áll, és jobb híján a megmaradt, még felhasználatlan U jelet alkalmazta rá.

Sajnálatos, hogy (egyelőre?) nem áll rendelkezésünkre több latin nyelvű szöveg rovásírással, így nem tudjuk megítélni, Szamosközy átírási elvei mennyiben felelhettek meg kora gondolkodásmódjának,

\footnotetext{
${ }^{26} \mathrm{Az}$ éles fekete tinta is nagyon elüt az eredeti vers fokozatosan fakuló barna tintájától. ${ }_{27}$ Talán ez segíthet megmagyarázni a mai napig érthetetlen talányt, a konstantinápolyi felirat miért balról jobbra halad.

${ }^{28}$ Vö. FERENCZI (1936: 69, 75. jz).
} 
mennyiben saját személyes ötletei. Ha azonban arra gondolunk, hogy a részletesebben tárgyalt négy emlék közül egyet csak 41 éve ismerünk, egynek pedig még valódi közlése nem volt, és a párhuzamként megemlített emlékek közt is van négy, melyeket körülbelül ennyi ideje tártak fel, jogosan reménykedhetünk abban, hogy e kérdésben is várhatók még újabb felfedezések.

\section{Felhasznált irodalom}

BENKŐ 1981

BENKŐ 1994a

BENKŐ 1994b

BENKŐ 1996

BENKŐ 2012

BENKŐ 2014

CSALLÁNY 1960

CSALLÁNY 1970

ERDÉLYI 1999

ERDÉLYI 2001

ERDÉLYI-RÁDULY 2010 ERDÉLYI I. - RÁDULY J., A Kárpát-medence rovásfeliratos emlékei a Kr. u. 17. századig, Budapest, 2010.

FEHÉR 2017

FEHÉR 2019

FERENCZI 1936

FERENCZI 1939

FERENCZI 1997

FORRAI 1985

FORRAI 1987

BENKŐ E., Középkori feliratok Dálnokon, Korunk, 40/15 (1981), 138145.

BENKŐ E., Régészeti megjegyzések székelyföldi rovásfeliratokhoz, MNy, 90 (1994), 157-167.

BENKŐ E., Középkori rovásfelirat Vargyasról, MNy, 90 (1994), 487489.

BENKŐ E., A székely rovásírás korai emlékei, MNy, 102 (1996), 75-79.

BENKŐ E., A középkori Székelyföld I., Budapest, 2012.

BENKŐ E., A székely írás középkori és kora újkori emlékei Erdélyben (Régészeti és történeti jegyzetek), in: Sudár B. - Szentpéteri J. (szerk.), Magyar őstörténet. Tudomány és hagyományőrzés, Budapest, 2014, 311-327.

CSALlÁNY D., A székely-magyar rovásírás emlékei, NyJAMÉ, 3 (1960), 39-125.

CSALLÁNY D., Székely rovásírásos szövegek megfejtése, Korunk, 29/4 (1970), 604-613.

ERDÉLYI I., Az újabb erdélyi rovásfeliratokról, Turán, 2(29)/3, (1999), 85-89.

ERDÉLYI I., Néhány szó a berekeresztúri református templom rovásfeliratáról, Turán, 4/2 (2011), 73.

FEHÉR J., Musnai Dakó György és festett munkái, in: Fehér J. - Gyöngyössy J. - Pál J., Tanulmányok Homoródszentmárton történetéhez, Piliscsaba 2017, 273-333.

FEHÉR B., Building inscriptions and mason's marks their potential touristic value. The example of the Firtos Runic Inscription, in: Wirth G. Köbli Á. (szerk.), Huncastle. Budapest 2019, 33-42.

FERENCZI S., Az énlaki rovásírásos felirat, Kolozsvár, 1936.

FERENCZI S., Rovásírásunk r jegye, EM, 44 (1939), 179-198.

FERENCZI G., Székely rovásírásos emlékek, Székelyudvarhely, 1997.

FORRAI S., Küskarácsontól Sülvester estig, Budapest, 1985.

FORRAI S., Kőbe vésett középkori nyelvemlék, Népszava, 115/227 (1987. IX. 26.), 9. 
FORRAI 1994

GÖMÖRI 2000

HORVÁTH 2010

HORVÁTH et al. 2011 HORVÁtH I. - HARANGOZÓ Á. - NÉMETH N. - TUBAY T., A Nikolsburgi Ábécé hitelességének kérdése. Előzetes közlemény. In: Boka L. - P. Vásárhelyi J. (szerk.), Szöveg - Kép - Emlék, Budapest, 2011, 76-90.

JAKUBOVICH 1935 JAKUBOVICH Emil, Das Kerbschrift-Alphabet von Nikolsburg, UJb, 15 (1935), 440-451.

KOMLÓSSY 2006

KÓNYA 1982

KÓNYA 1994

MANDICS 2010

NÉMETH 1934

PÁL 1966

RÁDULY 1995

RÉTHY 1888

SÁNDOR 1991

SÁNDOR 2014a

SÁNDOR 2014b

SEBESTYÉN 1909

SEBESTYÉN 1915

SEBESTYÉN 1929

TUBAY 2015

VÉKONY 1985

FORRAI S., Az ôsi magyar rovásírás az ókortól napjainkig, Lakitelek, 1994.

GÖMÖRI J., Az avar kori és X-XI. századi vaskohászat régészeti emiékei Somogy megyében, SMK, 14 (2000), 163-216.

HoRVÁTH I., Rovásírás: fel nem tett kérdések, előadás a Történelemtanárok Országos Konferenciáján, Budapest, 2010. [ma már nem érhető el az interneten, de az eredeti előadást volt szerencsém személyesen is hallani]

KOMLÓsSY Gy., Ósi betűk - mitikus történelem, ItK, 110 (2006), 529_ 538. = In: Varietas gentium, A XIII. Neolatin Világkongresszus előadásai, Szeged 2008, 137-146.

KÓNYA Á., Kilyén vallatása. Keresztény Magvető, 88 (1982), 210214.

KÓNYA Á., Vargyas újabb kincsei. Háromszék, 1194 (1994. VII. 30.), 1,4 .

MANDICs Gy., Róvott múltunk I-III., Arad, 2010.

NÉMETH Gy., A magyar rovásírás (A magyar nyelvtudomány kézikönyve II. 2), Budapest, 1934.

PÁL E., Suki Benedek kelyhe, Művészettörténeti Értesítő, 15 (1966), 89-111.

RÁDULY J., Rovásíró őseink, Korond, 1995.

RÉTHY L., Az úgynevezett hún-székely irás, Archaeologiai Értesítő, 8 (1888), 54-60.

SÁNDOR K., A Bolognai Rovásemlék (Magyar Östörténeti Könyvtár 1), Szeged, 1991.

SÁNDOR K., A székely irás nyomában, Budapest, 2014.

SÁNDOR K., A székely írás Székelyföldön kívüli használatának kezdetei, in: Sudár B. - Szentpéteri J. (szerk.), Magyar őstörténet. Tudomány és hagyományőrzés, Budapest, 2014, 329-342.

SEBESTYÉN Gy., Rovás és rovásírás, Budapest 1909. = Ethnographia 14 (1903), 1-29, 81-125, 161-189, 273-287, 313-340; 15 (1904), 241-255, 289-311, 337-422. Függelék: 17 (1906), 343-355.

SEBESTYÉN Gy., A magyar rovásírás hiteles emlékei, Budapest, 1915.

SEBESTYÉN Gy., Miként bizonyosodott be a székely rovásírás hitelessége? in: Csutak V. (szerk.), Emlékkönyv a Székely Nemzeti Múzeum ötvenéves jubileumára, Kolozsvár, 1929, 244-251.

TUBAY T., A székely írás kutatásának története, Budapest, 2015.

VÉKONY G., Késő népvándorláskori rovásfeliratok, Életünk 22/1 (1985), 71-84; 22/2 (1985), 147-169. 
VÉKONY 1987

VÉKONY 1999

VÉKONY 2004
VÉKONY G., Késő-népvándorláskori rovásfeliratok a Kárpátmedencében. Szombathely, 1987.

VÉKONY G., Székely írás legrégibb emléke Bodrog-Alsóbü vaskohászati mühelyéből, in: Gömöri János (ed.), Traditions and Innovations in the Early Medieval Iron Production, Sopron-Somogyfajsz, (1997) 1999, 226-229.

VÉKONY G., A székely irás emlékei, kapcsolatai, története, Budapest, 2004. 